(昭和 31 年 5 月 18 日受理)

\title{
染料固着剤の染色物耐光堅审度におよぼす影響について
}

\author{
群馬大学工業短期大学部 石 井 美 治

\section{EFFECTS OF FIXING AGENTS ON THE FADING OF THE DYED VISCOSE FILMS}

\author{
By Yoshiji Ishii
}

(Faculty of Technology, Gunma University, Kiryu, Japan)

The viscose films are dyed by some selected dyes, such as Chrysamine G, Direct Brown M, Benzo Cuprol Blue FBL, Benzo Copper Blue 2B and others. The film is treated with the aqueous solutions of the fixing agents, dicyandiamide-formaldehyde resin and Sapamine $\mathrm{KW}$, or cation active levelling agent, Repellate.

The absorption spectra of the films are measured and the deformation of the spectra by these treatments and by exposure to ultraviolet ray is discussed.

The results of these experiments are shown as follows:

(a) By the treatments of the agents the maximum wave length of spectra of dyes are shifted to shorter wave length side, and the fading of the dyed films is accelerated by these agents.

(b) By the modified treatment to which is added copper salt in the bath of the fixing agents, the fading of the films is greatly decreased, but has no relationship to the deformation of the spectra.

(c) The weak new absorption is developed on the dyed films with copper blue dyes at red side of the maximum wavelength of absorption curves. This new absorption is extinguished by fixing treatments, or exposure to ultraviolet ray. The reason of this phenomenon appears that the hydrogen bonding between the dyes and cellulose chain is cut, and the dyes are deposited in the film by fixing treatment or exposure to ultraviolet ray.

(Received 18, 5. 1956)

\section{1. 粕}

言

直接染料染色物の水洗堅审度を改善する後処理の一 つに, 固着剤(フィックス)に上る処理がある。本処 理は效果が優れ，工程が簡単で広く実施されているが, 処理品の耐光堅安度を低下させる場合があり，該処理 の久点となっている。対策としては，一般直接染料の 耐光堅牢度増進処理として周知の銅処理の併用が実施 され，をた固着剤中に銅塩を含ましめた製品が若干市 即されている。しかし銅処理はすべての染料に有效で はなく、サリチル酸をカップリングした染料とか、アゾ 基のオルソ位に水酸基を有する染料等に選択的仿有効 であるといわれ，なた固着剤の構造汇よる附光性低下 の程度も異なることが考光られるが，この上うな現象 に対する定量的な報告は未だ見出されない。著者は染 着された染料が，固着㓮または他の表面活性剤処理に より酎光度を低下する現象打よび硫酸銅処理併用の場 合の変化を，染色セロフフン膜を試料として研究した。

\section{2. 実 験 材 料 \\ 2.1 染料}

上記の通り銅処理により耐光性を著しく改善される 染料を主体とし粠造上類似のものとして，Oxamine Brown B を追加した下記 6 種のアゾ染料を使用した。 染料は，Robinson \& Mills の方法により精製した。 第 1 表に染料名，構造式を示した。

\section{2 被 染材 料}

染色物の裉色を直接測定できる便利さから，実駼は 系または布を使用することを止めて，ビスコース膜す なわちセロフフンを被染材料に選んだ。セロファンは 東京セロフフン KK 慗 No. 300 を蒸溜水で $24 \mathrm{hrs}$ 洗 湟し可溶性成分を流去したものである。染色は常法に より，助剂は食塩を適宜加えて使用染料がセロファン 飞吸尽されるよ5にした。吸尽されないるのは，残浴 比色により染着量を計算した。なお染色時間は $6 \sim 8$ hrs 沰騰し，12〜24hrs 放冷した。 
第1表使用染料 $の$ 槛造式

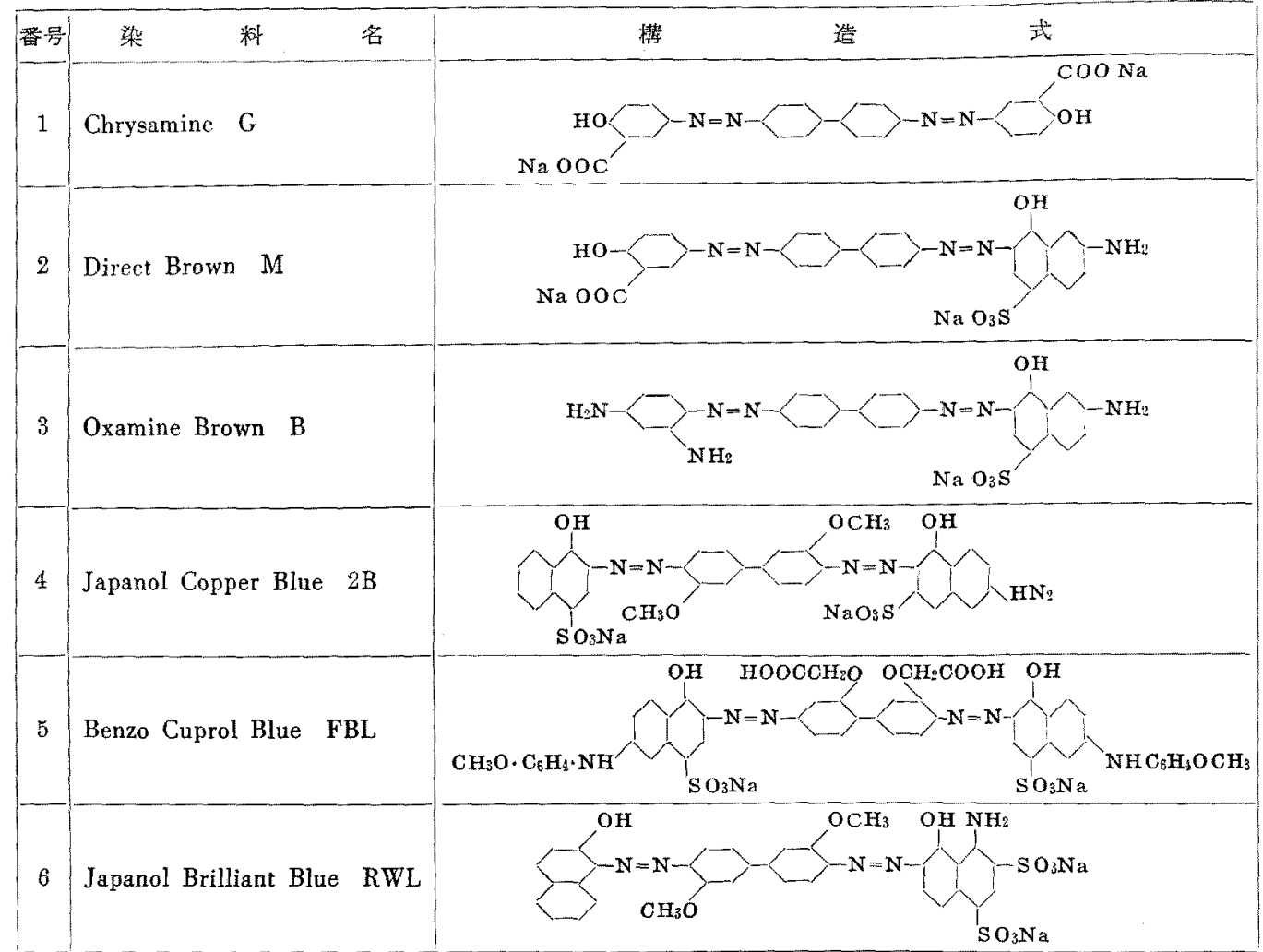

第 2 表 染色膜の染着濃度

\begin{tabular}{|c|c|c|}
\hline 番号 & 染料名 & 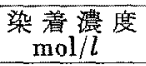 \\
\hline 1 & Chrysamine $\mathrm{G}$ & $2.80 \times 10^{-3}$ \\
\hline 2 & Direct Brown $\mathrm{M}$ & $3.06 \times 10^{-3}$ \\
\hline 3 & Oramine Brown $\mathrm{B}$ & $2,97 \times 10^{-3}$ \\
\hline 4 & Japanol Copper Blue 2B & $1.93 \times 10^{-3}$ \\
\hline 5 & Benzo Cuprol Blue FBL & $1.69 \times 10^{-3}$ \\
\hline 6 & Japanol Brilliant Blue RWL & $2.32 \times 10^{-3}$ \\
\hline
\end{tabular}

各染色試糊の染着殠度は第 2 表に示した。

\section{3 固畕剂・表面活性剂}

現在国内で生産されている固着風はほとんどすべて， ジシアンジミド,ホルマリン縮合物であるので, 某社 裴のフィックス、コンクをこの樹脂型の固着剤として 選んだ。また長鎖状分子の末端にカチオニックな基を 有する表面活性剤瑟の固着䠼の例として，Sapamine

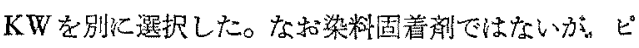
リシニニーム祸型の均染剤である Repellateを加光以 上 3 種の処理剤に上り後処理を実施した。いずれる市 販品または見本品をとのまま使用した。銅好理用とし ては，結昆硫酸鋁を使用した。

\section{3. 実 験方 法}

染色されたセロフフンはそれぞれ $1 \times 4 \mathrm{~cm}$ の単冊型 に切り日立分光光電光度計 EPB-U のセルホルダー に插入し，末染の膜を標準品とし，财収曲線を澌し た。

染色膜技よび標準膜はともに上記 3 種の処理斉 0.3 \%液に $70^{\circ} \mathrm{C}$ 〔10分間浸声した。しかる後再び吸収曲

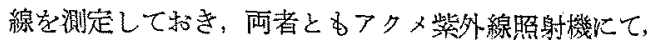
$2 \mathrm{hrs}$ 照射L，吸収曲線を測定し，再び照射を繰返し て, 6hrs 照射した。

鋁併用の㢦料もまた染色膜，標準膜の3 組を各染料 每に取り，処理放 $0.3 \%$, 硫酸銅 $0.03 \%$ 液にて上記 
同様に処理後, 紫外線 $2 \mathrm{hrs}$ 毎に照射, 裉色測定な゙繰 返した。

照射された末染標準七ロファンは肉腿的には変化が ないが，吸収曲線に短波長側で染色七ロファンと異な った吸光を示す心配があるので，測定波長は $360 \mathrm{~m} \mu$ 以上とした。

\section{4. 実験結果および考察}

\section{1 各種怒理による吸収曲線の変化}

第 1 〜図はそれぞ图中に示された染料によって 染色したせロファン膜の吸收曲線であり，哷軸は光学

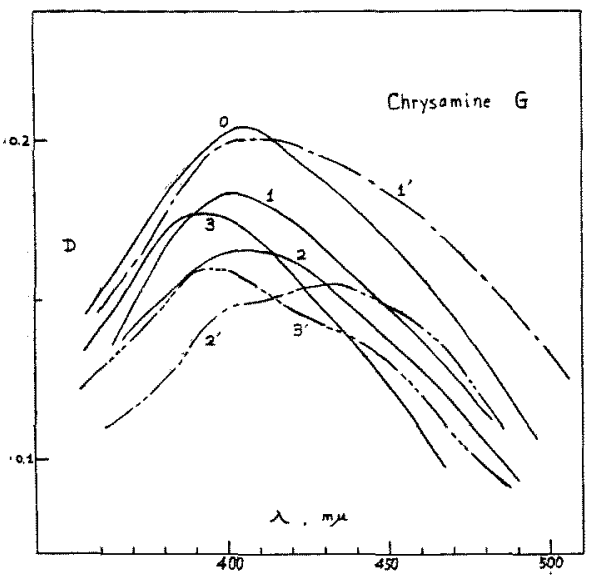

Fig. 1 Absorption spectra of Chrysamine $G$ in films

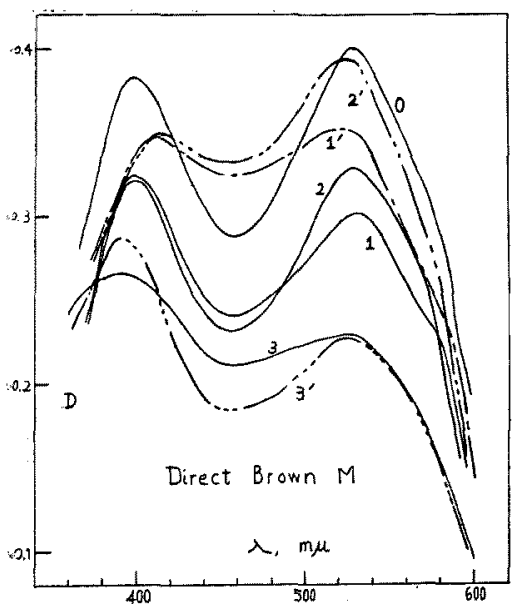

Fig. 2 Absorption spectra of Direct Brown $\mathrm{M}$ in films

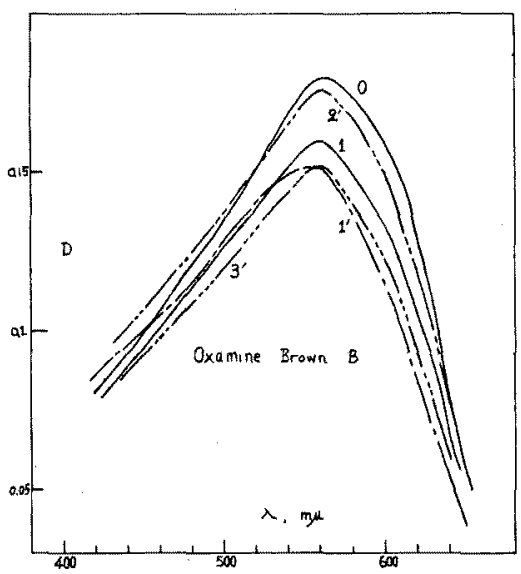

Fig. 3 Absorption spectra of Oxamine Brown $B$ in viscose films

密度，楛軸は波長 $(\mathrm{m} \mu)$ である。各図とも，曲線 0 は 染色，乾喿後のそれで，1，2および 3 を付した曲線 は，それぞれフィックス・コンク， Sapamine KW お。 よび Repellate で処理後櫘乾した膜，1'，2'およ゙ 3’を付した曲線は，それぞれ上記処理で銅イオンを 併用した膜の吸収曲線である。

各図に共通した曲線の溥化は各好理による吸光倸数 の低下であるが，処理浴侻落する染料は肉眼的に認 められず，処理による染料の脱馐を原因とすることは できない。各琶処理薬品が緎維素分子比着した色素 イオンに何らかの变化を与光たすのと考光られるが，

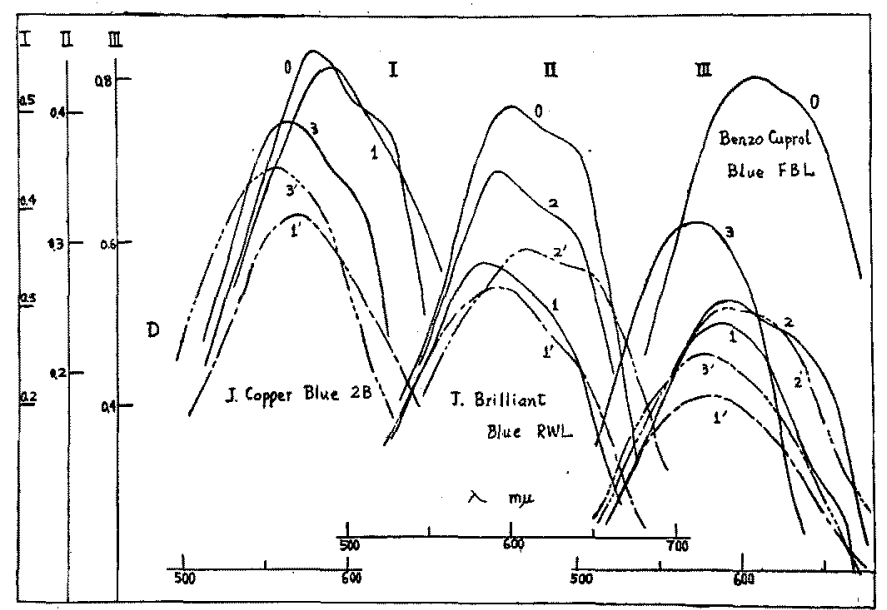

Fig. 4 Absorption spectra of Copper Blue Dyes in viscose films 
このことを議論することは困難であるので触れない。

周知の通り染料分子の吸収曲線は, その分子の基溸 状態と励起状態のエネルギ一差により決むるるので， 織維素分子中に収着した色素イオンの状態が变化すれ ば，上記エネルギー差に変化をきたし，㷈大吸收位置 は異なってくる。例えば該色素イオンに銅イオンが䏤 位して錯化合物を形成子机ば，当然乞の眀収曲線は変 化する。このような考克から各種処理による極大吸収 位置の移動について考察を進める。

第 1 図曲線 2 (以下番号で処理品の吸収曲線を示す)

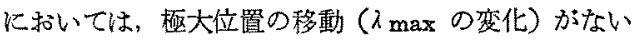
が，1および 3 亿おいては，短波長側への移動が約 5 $\sim 15 \mathrm{~m} \mu$ 見られる。な和銅侀用処理の場合, 極大位置 の移動は谨少で，長波長側の吸収增加が共通しだ著し い変化で劣る。後述の通り，銅処理用染料の銅イオン

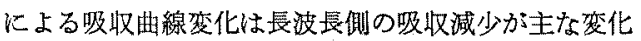
として認められるので, 銅偾用処理に和ける銅イオン

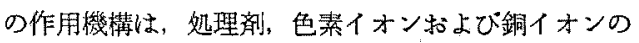
3者を考虑に入れるべきである。

第 2 図処理剂々上る極大位置の変化は僅少である。 本染料は可視部に 2 つの極大部圭有し，その極大部々 染料分子内 $\pi$ 電子系之の相関が確立されないのて推諭 の域老超点ないか，第 1 吸收 $(\lambda=515 \mathrm{~m} \mu)$ 第 2 吸収 $(\lambda=400 \mathrm{~m} \mu)$ 上り观理に上って相対的に低下している。 また銅併用处理の $1^{\prime}$ および 2 とては，第 1 四収極 大は短波長側，第 2 極大は長波長側化移動の㑯向があ る。3'亿ては吸収極大位置の移勤よりむしろ第 2 吸収 の吸收增加㵔しい。また本染料の紫外線照射による 裉色が主と乙て第 1 極大吸収の変化として現われるの で，第 2 極大吸収が，Chrysamine G K扝ける極大吸
収注対応するすのと推定する。

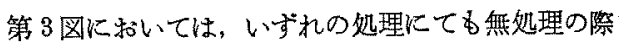
々極大位置はほとんご装らず，これら後処理特に銅併 用の際のサリシル酸基の重要性を想像ざる。

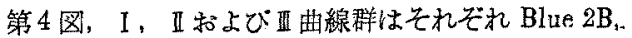
Blue RWL 扰よび Cuprol Blue FBL の吸収曲線を 示す。これらの染料怯銅処理火上り日光堅牢度を著し く增准することで知られている染料である。各染料と 6 0 曲線は極大吸収部の長波長側仁肩が隆起し, 大体 共通した曲線である。処理により長波長側に極大位の 移動した曲線怯，I群 1 曲線， II群 $2^{\prime}$ 曲線, 不变化 の曲線は，I群中 2 扰よび $2^{\prime}$ (四示せず)である。 他はすべて短波畏側への移動であった。これは第 1 〜 3 因と類似の傾向であるが，3者とも 1 曲線は共通し て長波長側の隆起を消失して, 前 3 図の染料に見られ ない吸収变化を示した。本隆起部の变化は別飞報告す るが，Brode ${ }^{1)}$ 等はアゾ染料水溶液について，全〈類 似の吸収曲線を得て，肩の隆起は色美イオンの水和作 よるものと考党た。またこれらる染料は硫酸銅の及の 水溶液で边理して見ると, 全部この隆起部老消失す る2。しかるに， I，代打よび正群とも Sapamine KW 銅処理 $2^{\prime}$ 曲線はこの隆起部を消失していない。この ことは上述の通り銅イォンが処理成に併用されると， 銅イオンの色素イオンに与兄る效果が变化する場合の あることを示す。

\section{2 処理品の紫外線による裉色}

Gill ${ }^{3)}$ は固着処理にて瀻維中の色素イオンは，集合。 沈㴬等の状態変化を生ずることを二色性から確かめた が，本実験子吸収曲線にかなりの变化があり袓色の際 の紫外線に上る染料の分解す簡単にランベルーベール

第 3 表 紫外線照射に上る最大光学密度低下率

\begin{tabular}{|c|c|c|c|c|c|c|c|}
\hline 染料名 & 起 理 & $\begin{array}{l}\text { フィックス } \\
=\text { Vy }\end{array}$ & $\begin{array}{c}\text { Sapamine } \\
\mathrm{KW}\end{array}$ & Repellate & $\begin{array}{l}\text { フィックス } \\
\text { בัy } \\
\text { 銅垪用 }\end{array}$ & $\begin{array}{l}\text { Sapamine } \\
\mathrm{KW} \\
\text { 銅垪用 }\end{array}$ & $\begin{array}{l}\text { Repellate } \\
\text { 銅用 }\end{array}$ \\
\hline Chrysamine G & 0.72 & 0.83 & $(0.80)$ & $(0.70)$ & 0.95 & $(0.93)$ & $(0,89)$ \\
\hline Direct Brown $\mathrm{M} *$ & 0.68 & 0.67 & 0.73 & 0.65 & 0.83 & 0.90 & 0.70 \\
\hline Oxamine Brown B & 0.67 & 0.56 & 0.60 & 0.63 & 0.67 & 0.78 & 0.80 \\
\hline Jap. Copper Blue 2B & 0.57 & $(0.49)$ & 0.58 & 0.48 & 0.64 & 0.95 & 0.90 \\
\hline B. C. Blue FBL & 0.73 & $(0.54)$ & 0.69 & 0.58 & 0.95 & 1.0 & $\overline{1.0}$ \\
\hline Jap. Bril. Blue RWL & 0.61 & 0.61 & 0.57 & 0.54 & 0.72 & 0.87 & 0.72 \\
\hline
\end{tabular}

*第1服取をとった 
の法則により算出することが不能となった。やむをえ 才゚光学密度低下率を染料の分解に比例する数として取 报った。

第 3 表岋無照射品を 1.0 とし紫外線 $6 \mathrm{hrs}$ 照射の極 大光学密度低下率である。

各処理により裉色は促進されるが, 若干の染料で無 処理より裉色しない例がある。第5図もとの例である が，紫外線の作用が極大部より短波長側に吸収の增加 をきたすため極大光学密度の低下が緩僈となっている。

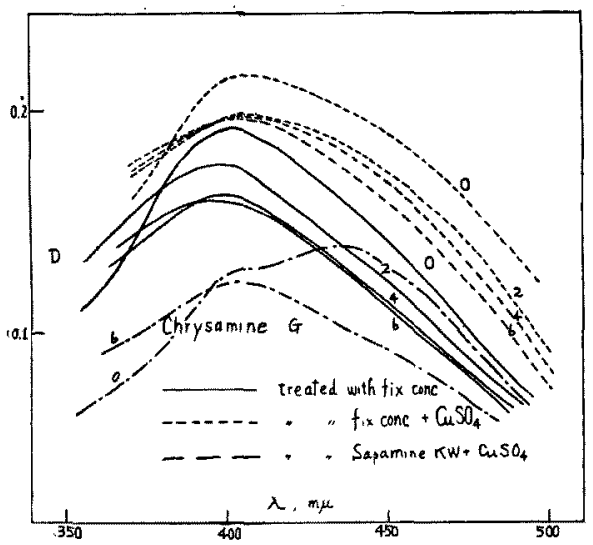

Fig. 5 Fading change of absorption curves in dyed films

な和频外線照射により曲線に著しい变化（極大部の 移動) の認められた例は第 3 表に括弧して区別しだ。 第 5 図に Sapamine KW 銅併用の例を示した。曲線 の数字は照射㭙間である。

第 3 表加 活性剤固着剂括よびビリジニユム塩 型均染㨈の裉色作用は概して促進さ れるが，若干の例で，逝の例が見党 た。な和观理剤の型に上万促進傾向 《は，Gill3) の指摘するような頵向 が見出されなかった。ただし個々の 染料以ついて言えば，吸収曲線に大 きな変化のあった例山裉色度が大き い。銅併用処理ては，全例に裉色阻 止作用があり，特に銅処理用染料て 甠影著である。Chrysamine G, Br•own M および Brown B で比較す ると，この順位で阻止作用が減少し ており，紫外線による色素イオンの
酸化分解に対する銅イオンの対抗作用も，染料棈造之 密接な関係がある。第6 図に示すごとく，Brown M では第 1 吸収が裉色の主な变化をきたしている。銅併 用品の第 2 吸収は紫外線照射に上り吸収增加を示し, Chrysamine G の短波長側の変化と比べて興味がある。

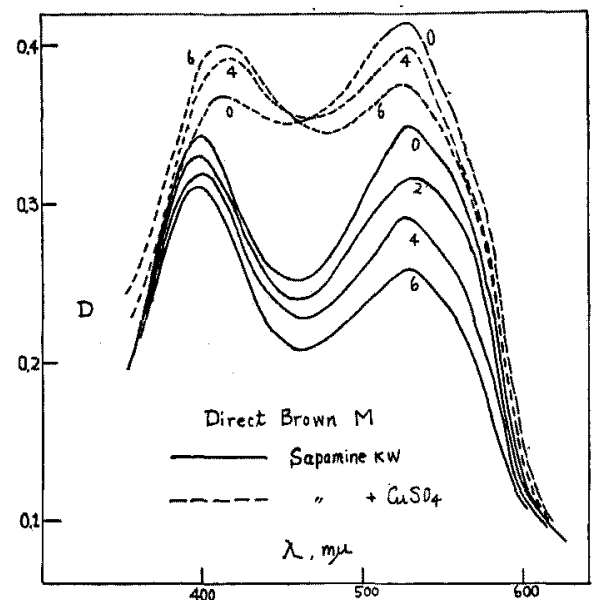

Fig. 6 Fading change of absorption curves in dyed films

鋼後処理用青色 3 染料に括いて，前述の通り処理に よる隆起部の変化があったが，大体このままの形で紫 外線により吸収を減少している。曲線变化恃第 7 図に 示した。たたし偽の部分が変化しなかった Sapamine $\mathrm{KW}$ 処理品はます紫外線によりこの隆起部が消失し，

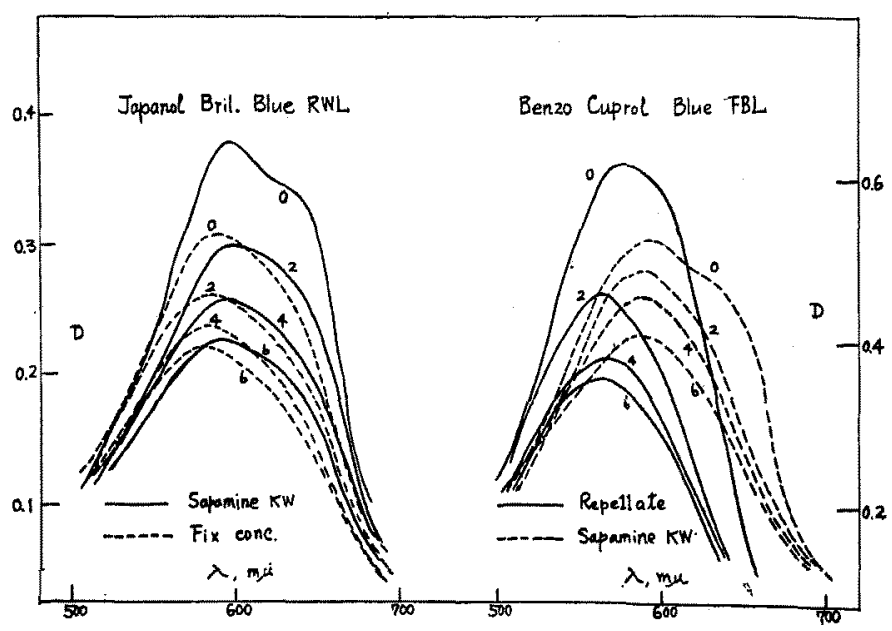

Fig. 7 Fading change of absorption curves of dyes in films 
吸収減少をきたす。また極大位固の移動したるのは短 波長侧入の移動で妨った。Brode

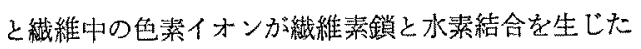
時, 隆起部が長波長側にできると推定されるので，本 処理または紫外楾照射は，色素イオンの瀻維への定方 位収着をくずし，光分解学起し裉色すると考えられる。

\section{5. 結}

び

樹脂型および表面活性型固着剤および均染放処理に より，染着染粘の昨収曲線は極大部が短波舆側に移る 傾向がある。裉色促進作用の大なる例はまた吸収曲線 の変化子著しい。たたし，澍脂型固着剤は常に表面活性 型のそれより裉色捉進作用が小である゙るといえない。 処理剂に銅イオンを併用すると，鋾イオンのみの吸 収曲線とは異なる埸合があり，処理剂，銅イオン安よ び色素イオンの3 者の相互作用が考无られるが，吸収 曲線恋化之相関性なく全例とも裉色阻止作用が現われ，
その程度は染料赫造に支即される。

銅処理用青色染料では，染着により新しい吸收が現 われるがここれは各処理または紫外線照射により消失 する。この現象は色素イオンの染着状態変化でりり䋗 維中の色素の流澱と推定した。

本研究は昭和30年度文部省科学研究助成補助金の交 付を受けた。心から当局に感謝する。なお実験に当り 御拹力を得大群馬大学工学部学生鈴木登喜男氏に感謝 の意を表する。

\section{文献}

1) W. R. Brode, I. L. Seldin, P. E. Spoerri \& G. M. Wyman; J.Am. Chem. Soc., 77, 2762 (1955), 2) 石井美治, 神山和已：昭和30年本学会秋期研究 発表会, 本誌投稿予定

3) R. Gill; J. Soc. Dyers \& Col., 71, 385 (19" 55)

\section{技術報文原稿募集について}

技術報文は工場現場に括ける技術上の新しい工夫，考穼，改良等を内容とするすので会員相互の知識交流 に役立つことを目的とするすのでありすす。従って会員各位に扔かれてはこの主旨に沿つて気軽に御投稿下 さるよう打願しすす。

応 募 要 項

（1）投稿規定は本学会の報文投稿規定に準拁する。但し英文抄録を添付する必要はない。又图面中の説明 は邦語でよい。

(2) 頁数は組上り 3 頁以内を原則とする。(本学会所定の原稿用紙で表, 图面等を含み 13 枚以内)

（3）内容，体裁等については本学会編集委員会に战いて多少の加筆，訂正をする場合がある。 